\title{
Generation of PTEN-knockout (--)) murine prostate cancer cells using the CRISPR/Cas9 system and comprehensive gene expression profiling
}

\author{
AKIKO TAKAO $^{1}$, KAZUHIRO YOSHIKAWA ${ }^{2}$, SIVASUNDARAM KARNAN $^{1}$, AKINOBU OTA ${ }^{1}$, \\ HIROTSUGU UEMURA ${ }^{3}$, MARCO A. DE VELASCO ${ }^{4}$, YURIE KURA ${ }^{3}$, SUSUMU SUZUKI ${ }^{5}$, \\ RYUZO UEDA $^{6}$, TOKIKO NISHINO ${ }^{2}$ and YOSHITAKA HOSOKAWA ${ }^{1}$ \\ ${ }^{1}$ Department of Biochemistry, Aichi Medical University School of Medicine; \\ ${ }^{2}$ Division of Research Creation and of Biobank, Research Creation Support Center, \\ Aichi Medical University, Nagakute, Aichi 480-1195; Departments of ${ }^{3}$ Urology, and ${ }^{4}$ Genome Biology, \\ Kindai University Faculty of Medicine, Osaka-Sayama, Osaka 589-8511; \\ ${ }^{5}$ Division of Research Support, Research Creation Support Center, ${ }^{6}$ Department of Tumor Immunology, \\ Aichi Medical University School of Medicine, Nagakute, Aichi 480-1195, Japan
}

Received December 15, 2017; Accepted July 30, 2018

DOI: $10.3892 /$ or.2018.6683

\begin{abstract}
Phosphatase and tensin homolog (PTEN) deficiency is associated with development, progression, and metastasis of various cancers. However, changes in gene expression associated with PTEN deficiency have not been fully characterized. To explore genes with altered expression in PTEN-deficient cells, the present study generated a PTEN-knockout cell line $(\triangle \mathrm{PTEN})$ from a mouse prostate cancer-derived cell line using the clustered regularly interspaced short palindromic repeats (CRISPR)/CRISPR-associated protein 9 (CRISPR/Cas9) gene editing system. Following transfection of the CRISPR/Cas9 construct, DNA sequencing was performed to identify deletion of the Pten locus and PTEN inactivation was verified by western blotting. The $\triangle$ PTEN cell line exhibited enhanced RAC-alpha serine/threonine-protein kinase phosphorylation and cyclin D1 expression. In addition, an increase in cell proliferation and colony formation was observed in the $\triangle$ PTEN cell line. Gene expression profiling experiments were analyzed with microarray and microRNA (miRNA) arrays. In the microarray analysis, 111 genes exhibited $\geq 10$-fold increased expression compared with the parent strain and mock cell line and 23 genes were downregulated. The only
\end{abstract}

Correspondence to: Dr Kazuhiro Yoshikawa, Division of Research Creation and of Biobank, Research Creation Support Center, Aichi Medical University, 1-1 Yazakokarimata, Nagakute, Aichi 480-1195, Japan

E-mail: yoshikaw@aichi-med-u.ac.jp

Key words: phosphatase and tensin homolog, clustered regularly interspaced short palindromic repeats/CRISPR-associated protein 9, gene editing, microarray, microRNA arrays
miRNA with increased expression of 10 -fold or more was mmu-miR-210-3p. Genes with enhanced expression included genes involved in the development, progression, and metastasis of cancer such as Tet methylcytosine dioxygenase 1, twist family BHLH transcription factor 2, C-fos-induced growth factor and Wingless-Type MMTV Integration Site Family, Member 3, and genes involved in immunosuppression such as Arginase 1 . The results of the present study suggest that PTEN deficiency mobilizes a variety of genes critical for cancer cell survival and host immune evasion.

\section{Introduction}

Phosphatase and tensin homolog (PTEN) is a tumor suppressor and a lipid phosphatase that catalyzes dephosphorylation of phosphatidylinositol 3,4,5-trisphosphate. PTEN has a high frequency of mutations in various cancers including prostate cancer and glioblastoma. PTEN alterations are observed in approximately half of all malignant tumors and correlate with increased RAC-alpha serine/threonine-protein (AKT) phosphorylation and initiation of downstream targets that modulate a wide range of cellular processes associated with the progression of tumor growth and survival (1-8).

To investigate the function of PTEN, various knockout mice have been prepared and the effect of PTEN deficiency examined (9). The authors also established a conditional PTEN-deficient mouse model of prostate cancer driven by the $P S A$-Cre promoter and demonstrated its utility in various experimental settings (10-13). To develop better treatment strategies requires a deeper understanding the cellular and molecular mechanisms of PTEN deficiency. However, autochthonous tumors are highly heterogeneous and are composed of a complex tumor microenvironment that consists of various cell types including epithelial cancer cells, stromal fibroblasts, immune endothelial and blood cells, in addition to other 
contaminants, all of which contribute to the molecular characterization of PTEN deficiency. Although small interfering RNA methodology enables us to induce PTEN-deficiency at the protein level (14), researchers often take into consideration the fact that gene expression still remains at a certain level even under conditions of gene knockdown.

Next-generation genome editing strategies have been developed and are currently considered some of the best technological tools to most efficiently characterize gene function (15). The present study generated an isogenic PTEN-deficient cell clone from a parental mouse prostate cancer cell line using the clustered regularly interspaced short palindromic repeats (CRISPR)/CRISPR-associated protein 9 (CRISPR/Cas9) system and performed comprehensive gene expression profiling analyses to identify its impact on unique genes associated with crucial roles in cellular processes, including cancer development and immunity.

\section{Materials and methods}

Cell lines. The mouse prostate cancer cell line, 2924V, which expresses wild-type PTEN was used in the present study. This cell line was established from a prostate tumor originating from a 57 week-old $P S A^{\text {Cre }} ;$ Pten $^{\text {loxPlloxP }}$ conditional knockout mouse (10). Cells were cultured at $37^{\circ} \mathrm{C}$ and $5 \%$ $\mathrm{CO}_{2}$ in RPMI-1640 medium (Sigma-Aldrich; Merck KGaA, Darmstadt, Germany) supplemented with $10 \%$ inactivated fetal bovine serum (HyClone; GE Healthcare Life Sciences, Logan, UT, USA), $100 \mathrm{IU} / \mathrm{ml}$ penicillin, and $100 \mu \mathrm{g} / \mathrm{ml}$ streptomycin.

PTEN-knockout using the CRISPR/Cas9 system. The CRISPR/Cas9 system was used to disrupt the expression of the PTEN gene as described previously (16).pSpCas9(BB)-2A-Puro (PX459) was a gift from Feng Zhang (Broad Institute of MIT, Harvard, MA, USA; Addgene plasmid \#48139; 15). Briefly, a single guide RNA (sgRNA) sequence was selected using Optimized CRISPR Design (http://crispr.mit.edu/). The sgRNA sequence targeting PTEN was 5'-GCTAACGATCTCTTTGAT GA -3'. The plasmid expressing human Cas9 and the PTEN sgRNA was prepared by ligating oligonucleotides into the $B b s I$ site of PX459 (Pten/PX459). To establish a PTEN knockout clone with a one-nucleotide deletion, $2924 \mathrm{~V}$ cells $\left(1 \times 10^{6}\right.$ cells/dish $)$ were seeded in a $10-\mathrm{cm}$ dish. Cells were then transfected with $10 \mu \mathrm{g}$ of PTEN/PX459 using Lipofectamine ${ }^{\circledR} 3000$ (Thermo Fisher Scientific, Inc., Waltham, MA, USA). Antibiotic selection (puromycin; $2 \mu \mathrm{g} / \mathrm{ml}$ ) was begun $72 \mathrm{~h}$ after transfection and continued for at least 3 days. A single clone was selected, expanded, and then used for biological assays. For sequence analysis of the PTEN gene, the following primer set was used: 5'-CGCTAATCCAGTGTACAGTA-3' and 5'-CTGCGAGGA TTATCCGTCTT-3'.

Morphology. The cells were plated in a 12-well plate. After $24 \mathrm{~h}$, the cell morphology was digitally photographed at x 100 magnification using an inverted microscope system (IX73: Olympus Corporation, Tokyo, Japan).

MTT assay. Briefly, parent cells, mock cells, and $\triangle$ PTEN were seeded $\left(5 \times 10^{3}\right.$ cells/well) into a 96 -well plate. Subsequently, 10- $\mu 1$ MTT solution (5 $\mu \mathrm{g} / \mathrm{ml}$; Sigma-Aldrich; Merck KGaA,
Darmstadt, Germany) was added to each well and cells were incubated at $37^{\circ} \mathrm{C}$ in $5 \% \mathrm{CO}_{2}$ for $4 \mathrm{~h}$. Next, cell lysis buffer [10\% sodium dodecyl sulfate (SDS) in $0.01 \mathrm{M} \mathrm{HCL}$ ] was added to the wells to dissolve the formazan crystals produced by MTT. The optical density $(550 \mathrm{~nm})$ at each time point (day $0,1,3,5$, and 7 ) is presented as the mean \pm standard error of the mean $(n=6)$.

Colony formation assay. Colony formation assays were performed by seeding 500 cells of each line in 12-well plates. After 14 days, cells were fixed/stained with $3.7 \%$ formaldehyde (Wako Pure Chemical Industries, Ltd., Osaka, Japan) containing $0.2 \%(\mathrm{wt} / \mathrm{vol})$ crystal violet (Sigma-Aldrich; Merck KGaA) at room temperature and number of colonies were imaged and counted manually. Bar graphs represent the number of stained colonies. Data are presented as the mean \pm standard error of the mean $(n=3)$.

Western blotting. Cells were lysed in radioimmunoprecipitation assay buffer (Wako Pure Chemical Industries, Ltd.) supplemented with a protease inhibitor cocktail (Roche Applied Science, Mannheim, Germany) for $30 \mathrm{~min}$ at $4^{\circ} \mathrm{C}$. Insoluble material was removed by centrifugation at $15,400 \mathrm{x}$ g for $10 \mathrm{~min}$ at $4^{\circ} \mathrm{C}$. Protein content was determined using a DC protein assay kit (5000112JA; Bio-Rad Laboratories, Inc., Hercules, CA, USA) according to the manufacturer's protocol. Protein lysates were mixed with loading buffer and boiled for $5 \mathrm{~min}$. A total of $10 \mu \mathrm{g}$ protein was separated by electrophoresis on $10 \%$ PAGE gels (TEFCO, Tokyo, Japan). Proteins were then transferred to Immobilon-P membranes (EMD Millipore, Billerica, MA, USA) and blocked in 5\% skim milk in Tris-buffered saline with $0.01 \%$ Tween-20 (TBS-T) for $1 \mathrm{~h}$ at room temperature. All antibodies were purchased from Cell Signaling Technology, Inc. (Danvers, MA, USA). Membranes were incubated with primary antibodies [PTEN, 1:3,000, \#9559; AKT1, 1:1,000, \#9272; phosphorylated (p)-AKT, 1:1,000, \#9271; phosphorylated (p)-Rb, 1:3,000, \#9307; cyclin D1, 1:3,000, \#2922; CDC2, 1:3,000, \#9112; CDK2, 1:3,000, \#2546; CDK4, 1:3,000, \#2906; CDK6, 1:1,000, \#3136; CDK7, 1:1,000, \#2916 and GAPDH 1:5,000, \#5174] overnight at $4^{\circ} \mathrm{C}$. After three washes with TBS-T, membranes were incubated with anti-mouse, \#7076/rabbit, \#7074, horseradish peroxidase (HRP)-conjugated secondary antibody $(1: 5,000)$ for $1 \mathrm{~h}$ at room temperature followed by a final wash. Proteins were detected by applying ImmunoStar LD (Wako Pure Chemical Industries, Ltd.) to the membrane and signals were quantified using ImageQuant LAS-4000 (GE Healthcare Life Sciences, Little Chalfont, UK) according to the manufacturer's protocol.

RNA extraction. For microarray analysis, reverse transcription (RT)-polymerase chain reaction (PCR) and quantitative (q) PCR, total RNA was extracted from cell lines with the NucleoSpin RNA kit (Macherey-Nagel, Düren, Germany) according to the manufacturer's protocol. RNA extraction for miRNA analysis was performed with the MiRNeasy Mini Kit (Qiagen GmbH, Hilden, Germany) according to the manufacturer's protocol.

Microarray analysis. Expression profiling analysis of mRNA was performed using the Agilent Oligo Microarray Kit (8x60 K; 
Table I. Primers used for polymerase chain reaction.

\begin{tabular}{llcll}
\hline $\begin{array}{l}\text { Gene } \\
\text { name }\end{array}$ & Accession & $\begin{array}{c}\text { Relative intensity } \\
\text { of KO/mock }\end{array}$ & \multicolumn{1}{c}{ Forward primer } & \multicolumn{1}{c}{ Reverse primer } \\
\hline Tetl & NM_001253857 & 32 & ACACAGTGGTGCTAATGCAG & AGCATGAACGGGAGAATCGG \\
Twist2 & NM_007855 & 13 & TACAGCAAGAAATCGAGCGAAG & GCTGAGCTTGTCAGAGGGG \\
Arg1 & NM_007482 & 12 & CTCCAAGCCAAAGTCCTTAGAG & GGAGCTGTCATTAGGGACATCA \\
Figf & NM_010216 & 10 & AACAGATCCGAGCAGCTTCTA & TTTTGAGCTTCAACCGGCATC \\
Wnt3 & NM_009521 & 10 & AGCGTAGCAGAAGGTGTGAAG & CCAGGTGGCCCCTTATGATG \\
Galnt14 & NM_027864 & -19 & CTCATCAAACTGCTCCCACA & GCTCTGGATCACCGTACTGC \\
Ptgrl & NM_025968 & -30 & CAATCGTTCCTTTTGGGAAG & CATGAGAGTTGCAGCCAAAA \\
\hline
\end{tabular}

Tet1, Tet methylcytosine dioxygenase 1; Twist2, twist family BHLH transcription factor 2; Arg1, Arginase 1; Figf, c-fos induced growth factor; Wnt3, Wint family member 3; Ptgr1, prostaglandin reductase 1; Galnt14, polypeptide N-acetylgalactosaminyltransferase 14.

G4852B; Agilent Technologies, Inc., Santa Clara, CA, USA). Nucleic acid labeling and hybridization were performed with the One-Color Microarray-Based Gene Expression Analysis kit (Agilent Technologies, Inc.) according to the manufacturer's protocol. Briefly, $100 \mathrm{ng}$ of total RNA was amplified and labeled using the Low Input Quick Amp Labeling Kit. After labeling, RNA was purified with RNeasy Mini Kit (Qiagen $\mathrm{GmbH}$ ). The RNA fragmentation reaction was performed at $60^{\circ} \mathrm{C}$ for $30 \mathrm{~min}$, after which the samples were collected on ice for $1 \mathrm{~min}$, and 2X Hi-RPM Hybridization Buffer was added to stop the reaction. Samples were further mixed, centrifuged at $13,000 \mathrm{x} \mathrm{g}$ for $1 \mathrm{~min}$ at room temperature, placed on ice, and then loaded onto the array. The arrays were hybridized at $65^{\circ} \mathrm{C}$ for $17 \mathrm{~h}$. The microarray slides were then washed with Gene Expression Wash Buffers I and II and scanned with the Agilent Microarray Scanner-G2505C (Agilent Technologies, Inc.). Feature Extraction Software Version 11.0.1.1 (Agilent Technologies, Inc.) was used to extract and analyze the signals and signal intensities were normalized as previously described (17).

The background signals were normalized and microarray expression data were rank-ordered according to the expression levels of the $\triangle \mathrm{PTEN} /$ mock cells. Differentially expressed genes between $\triangle \mathrm{PTEN}$ and mock cells were considered relevant if there was $\geq 10$-fold change.

Functional enrichment analyses of differentially expressed genes were carried out using the Panther web-based tool (18).

To confirm gene expression, RT-qPCR was performed using the ABI 7900 HT Fast Real-Time PCR System (Applied Biosystems; Thermo Fisher Scientific, Inc.) and calculated using the $2^{-\Delta \Delta \mathrm{Cq}}$ method (19). Total RNA from the three cell lines were converted to cDNA with the High Capacity cDNA Reverse Transcription Kit (Applied Biosystems; Thermo Fisher Scientific, Inc.) according to the manufacturer's protocol. The Tet methylcytosine dioxygenase 1 (Tet1), twist family BHLH transcription factor 2 (Twist2), arginase 1 (Arg1), C-fos induced growth factor (Figf), Wingless-Type MMTV Integration Site Family, Member 3 (Wnt3), prostaglandin reductase 1 (Ptgr1), polypeptide $\mathrm{N}$-acetylgalactosaminyltransf erase 14 (Galnt14), and GAPDH (reference) genes were amplified and detected using SYBR-Green (Applied Biosystems; Thermo Fisher Scientific, Inc.). PCR reactions were prepared in a final volume of $20 \mu \mathrm{l}$, with $17.6 \mu \mathrm{l}$ of SYBR-Green PCR
Master Mix (Applied Biosystems; Thermo Fisher Scientific, Inc.), $2.0 \mu \mathrm{l}$ of DNA, and $0.2 \mu \mathrm{l}$ each of the $10 \mathrm{pmol} / \mu \mathrm{l}$ forward and reverse primers. Thermal cycler settings included DNA polymerase activation at $95^{\circ} \mathrm{C}$ for 2 min followed by 55 cycles of denaturation at $95^{\circ} \mathrm{C}$ for $15 \mathrm{sec}$, annealing at $60^{\circ} \mathrm{C}$ for $15 \mathrm{sec}$, and extension at $70^{\circ} \mathrm{C}$ for $20 \mathrm{sec}$. Each measurement was performed in triplicate. The quality of the PCR products was monitored by using the post-PCR melt-curve analysis.

In order to visualize PCR Products, PCR was carried out changing the number of cycles to 30 cycles. The PCR products were electrophoresed in $1.5 \%$ agarose gel, and stained with GelRed Nucleic Acid Stain (41003-T; Biotium, Inc., Fremont, CA, USA) and photographed. Primer sequences are listed in Table I.

miRNA array analysis. miRNA profiling analysis was performed using the Agilent Mouse miRNA kit (8x60 K; G4872A-070155). miRNA labeling, hybridization, and washing were carried out according to the manufacturer's protocol (Agilent Technologies, Inc.). Hybridized microarrays were scanned with a DNA microarray scanner (Agilent Microarray Scanner; G2505C) and features were extracted using the Agilent Feature Extraction image analysis tool (version 11.0.1.1). Briefly, average values of the spots of each miRNA were background-subtracted and subjected to further analysis. miRNA array expression data were rank-ordered according to the expression levels of the $\triangle$ PTEN/mock cells. To confirm miRNA expression level, RT-qPCR was performed. Total RNA from the three cell lines were converted to cDNA with the Taqman MicroRNA Reverse Transcription Kit (Applied Biosystems) according to the manufacturer's protocol. Realtime PCR was performed using Taqman MicroRNA Assays (has-miR-210, RT:000512 and snoRNA234; RT:001234 as control; Applied Biosystems) according to the manufacturer's protocol.

Statistical analysis. At least three replications per experiment and three independent experiments were performed. The results are expressed as the mean \pm standard error of the mean. Independent-samples Student's t-test and one-way analysis of variance, followed by the least significant difference post-hoc test were performed to analyze data using JMP Ver.13.2.1 
A

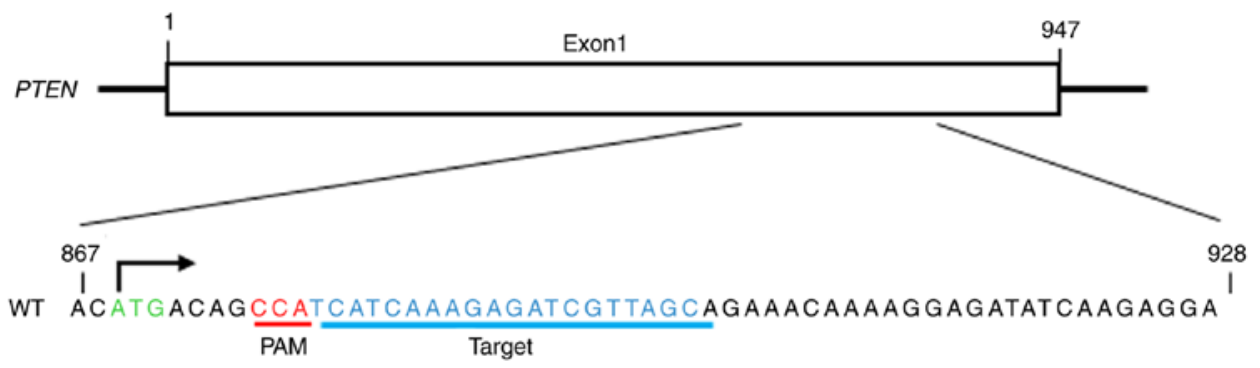

B

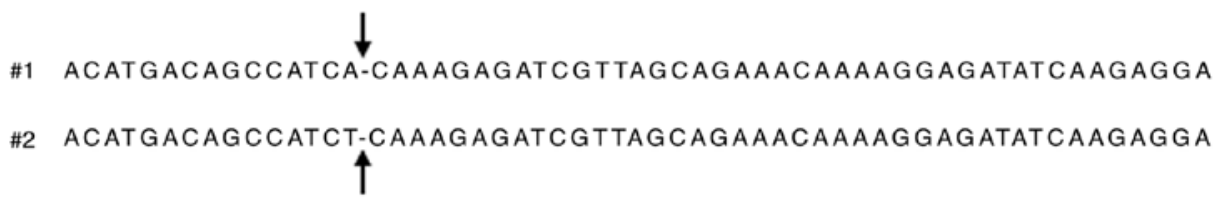

C
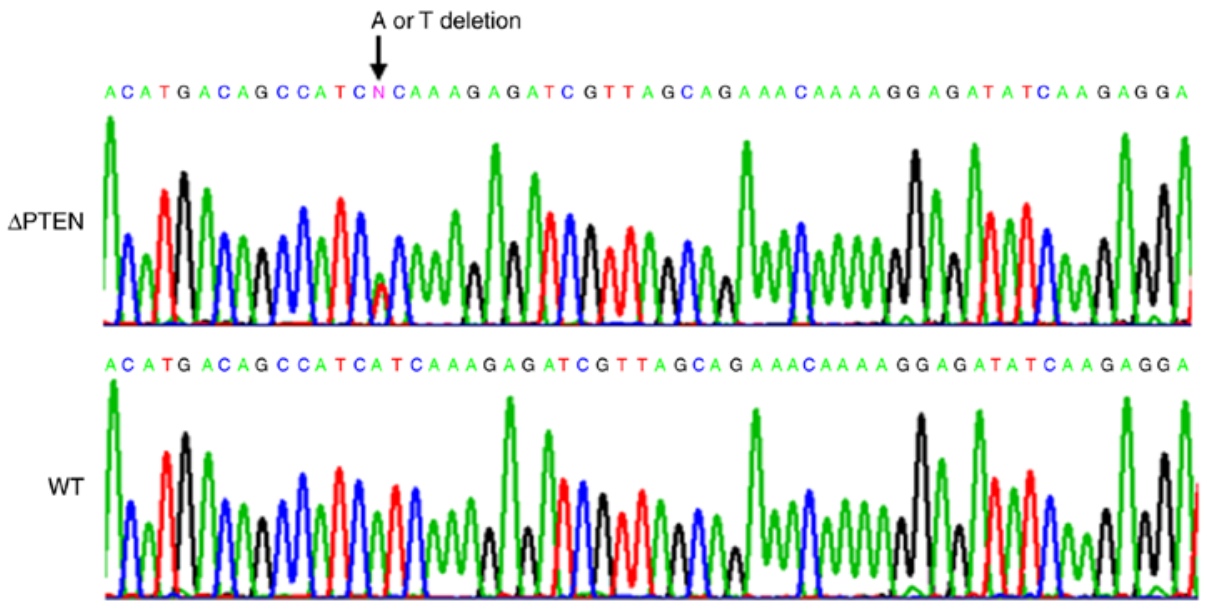

Figure 1. Generation of a PTEN-knockout cell line using the CRISPR/Cas9 gene editing system. (A) An sgRNA sequence was designed against the mouse PTEN gene to delete a nucleotide in the target sequence indicated by the underlined blue text. The PAM sequence is indicated by the underlined red text and in-frame ATG is indicated in green. (B) The DNA sequence of two alleles of cells genetically edited with the CRISPR/Cas9 system. The black arrows indicate the deleted sites. (C) DNA sequence analysis of two alleles showing the PTEN mutation. The black arrows indicate the deleted site. The WT sequence is from the parental cell line. PAM, protospacer adjacent motif; WT, wildtype; PTEN, phosphatase and tensin homolog; CRISPR/Cas9, clustered regularly interspaced short palindromic repeats/CRISPR-associated protein; $\triangle$ PTEN, PTEN-knockout cell line.

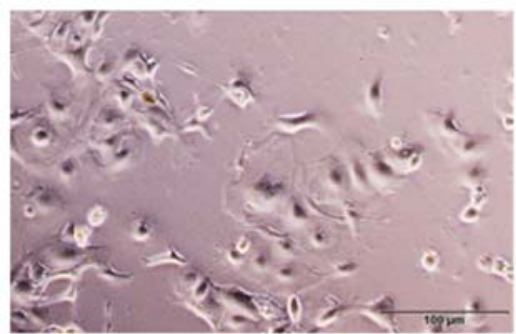

$\triangle P T E N$

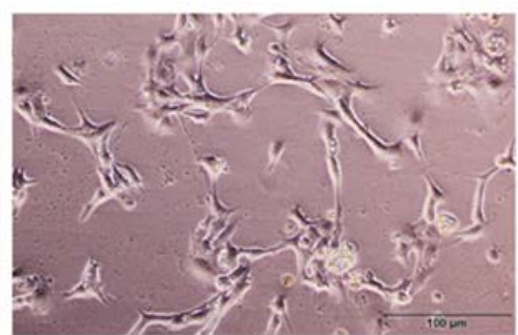

Mock

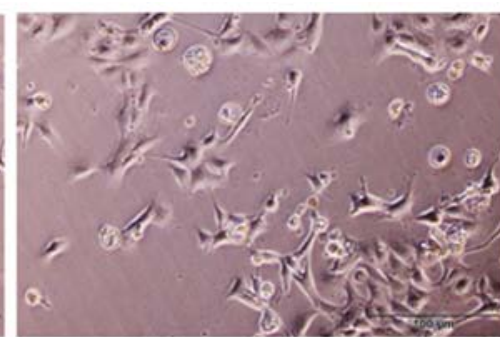

Parental

Figure 2. Photomicrograph depicting cell morphology in $\triangle \mathrm{PTEN}$, mock and parental cell lines. PTEN, phosphatase and tensin homolog; $\triangle \mathrm{PTEN}$, PTEN-knockout cell line.

(SAS Institute Inc; Tokyo, Japan). $\mathrm{P}<0.05$ was considered to indicate a statistically significant difference $\left({ }^{*} \mathrm{P}<0.05 ;{ }^{* *} \mathrm{P}<0.01\right.$; $\left.{ }^{* * *} \mathrm{P}<0.001\right)$.

\section{Results}

Establishment of PTEN-knockout cells using the CRISPR/Cas9 System. The present study performed genome editing (targeting sequence presented in Fig. 1A) using the CRISPR/Cas9 system and obtained multiple clones ( $\triangle \mathrm{PTEN})$. Fig. $1 \mathrm{~B}$ and $\mathrm{C}$ reveal DNA sequencing of target sites in the resultant clones. These results demonstrated that targeting PTEN with the CRISPR/Cas9 system effectively generated mutant-PTEN clones. Next, the present study assessed the effects of PTEN inactivation in the resulting clones. Overall, the general appearance was similar between parental, mock, and $\triangle$ PTEN cells; however, marginal differences were observed in the morphological appearance of $\triangle$ PTEN cells such as heterogeneity of the cell shape (Fig. 2). 


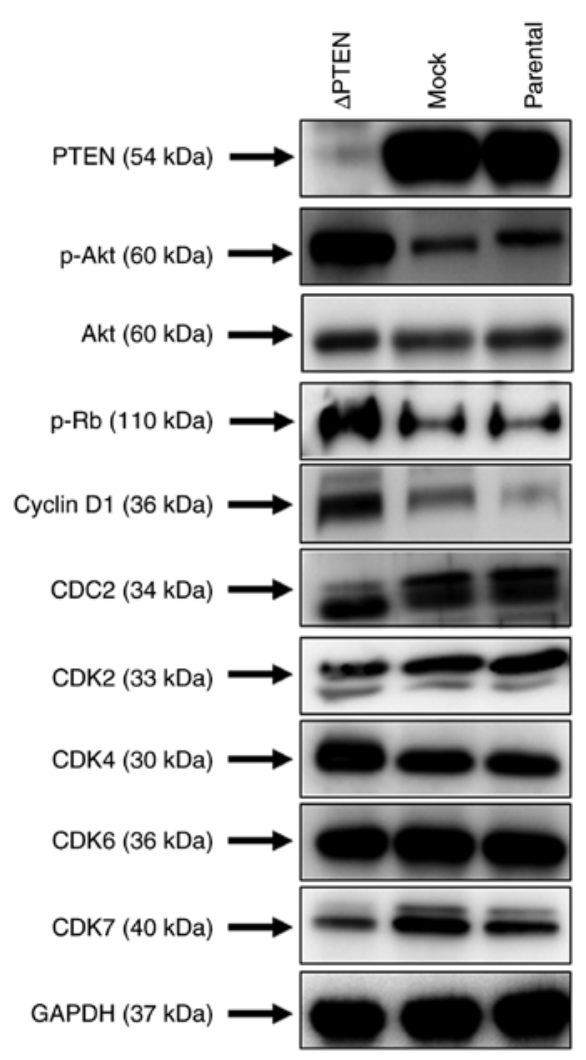

Figure 3. Western blot analysis of $\triangle \mathrm{PTEN}$ cells. Immunoblots showing protein expression of basal PTEN, phospho-Akt, and the cell cycle-related proteins pRb, Cyclin D1, CDC2, CDK2, CDK4, CDK6, and CDK7 in $\triangle$ PTEN, mock and parental cell lines. GAPDH was used as a loading control. PTEN, phosphatase and tensin homolog; $\triangle$ PTEN, PTEN-knockout cell line; $\mathrm{CDK}$, cyclin dependent kinase; $\mathrm{CDC} 2$, cyclin-dependent protein kinase 1; p, phosphorylated; Akt, RAC-alpha serine/threonine-protein kinase; $\mathrm{Rb}$, retinoblastoma tumor-suppressor protein.

Using western blot analysis, the present study verified the effective knockout of PTEN in $\triangle$ PTEN cells. Fig. 3 shows that the expression of PTEN was present in the parental strain and mock-transfected cells but was effectively downregulated in $\triangle$ PTEN cells. Accordingly, Akt phosphorylation levels increased in the absence of PTEN. Activation of the PI3K/Akt pathway promotes the cellular proliferation of transformed cells; thus, the expression of molecules involved in proliferation was then assessed. In $\triangle \mathrm{PTEN}$ cells, the upregulation of Akt phosphorylation was associated with the elevated expression of cyclin D1, cyclin dependent kinase (CDK)4, and decreased expression of CDK7. In addition, increased phosphorylation of the retinoblastoma tumor-suppressor protein (RB) was observed, a known regulator of cellular proliferation, in $\triangle$ PTEN cells. As the expression of molecules involved in the cell cycle was demonstrated to be enhanced in $\triangle$ PTEN cells, the present study then assessed the effects of PTEN inactivation on cell viability. Fig. 4 shows that the inactivation of the PTEN function in $\triangle$ PTEN cells results in increased cell growth and enhanced colony formation.

Microarray and miRNA array analysis of PTEN-knockout cells. Using gene microarrays, the present study assessed changes in gene expression following the loss of the PTEN function and focused on genes that were differentially expressed in $\triangle$ PTEN cells relative to mock-transfected cells and the parental strain (Fig. 5). Overall, 111 genes were
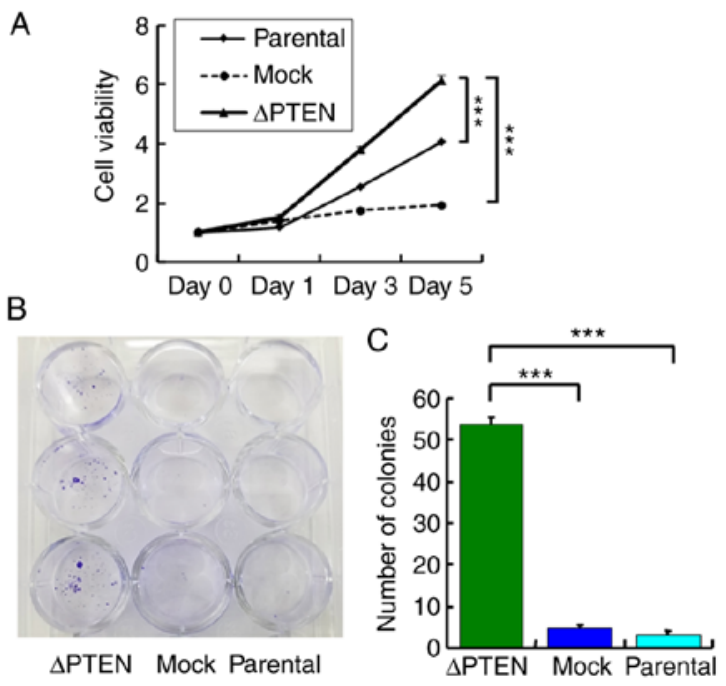

Figure 4. PTEN-knockout enhances cell viability and colony formation. (A) MTT analysis of growth curves of $\triangle \mathrm{PTEN}$, mock and parental cells. The optical density $(550 \mathrm{~nm})$ at each time point (day $0,1,3,5$ and 7$)$ is presented as the mean \pm standard error of the mean $(n=6)$. (B) A colony formation assay was performed by seeding 500 cells into six-well plates. After 14 days, the cells were stained with crystal violet and imaged. (C) Representative micrographs and quantification of colonies. Values are presented as the mean \pm standard error of the mean $(n=3){ }^{* * * * *} \mathrm{P}<0.001$. PTEN, phosphatase and tensin homolog; $\triangle$ PTEN, PTEN-knockout cell line.

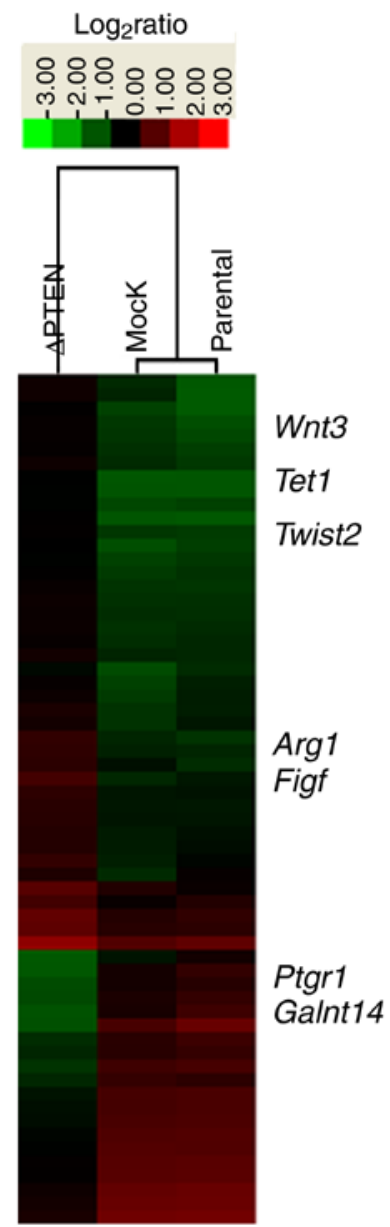

Figure 5. Microarray analysis identification of novel genes associated with PTEN expression. Heat map representing gene expression changes (at least 10-fold) in $\triangle$ PTEN, mock, and parental cells. PTEN, phosphatase and tensin homolog; $\triangle$ PTEN, PTEN-knockout cell line; Tet1, Tet methylcytosine dioxygenase 1; Figf, C-fos-induced growth factor; Twist2, twist family BHLH transcription factor 2; Arg1, Arginase 1; Ptgr1, prostaglandin reductase 1; Galnt14, polypeptide N-acetylgalactosaminyltransferase 14 . 
Table II. Genes that are upregulated 10-fold or more in phosphatase and tensin homolog knockout cells.

\begin{tabular}{|c|c|c|c|c|}
\hline Gene symbol & Accession & UniGene & Function & $\begin{array}{l}\text { Relative intensity } \\
\text { of } \mathrm{KO} / \mathrm{mock}\end{array}$ \\
\hline Sprr2d & NM_011470 & Mm.87820 & Small proline-rich protein $2 \mathrm{D}$ & 74 \\
\hline Serpinb6b & NM_011454 & Mm.36526 & $\begin{array}{l}\text { Serine (or cysteine) peptidase inhibitor, } \\
\text { clade } \mathrm{B} \text {, member } 6 \mathrm{~b}\end{array}$ & 36 \\
\hline Lifr & NM_013584 & Mm.149720 & Leukemia inhibitory factor receptor & 36 \\
\hline Tet1 & NM_001253857 & Mm.491965 & Tet methylcytosine dioxygenase 1 & 32 \\
\hline Sprr2e & NM_011471 & Mm.261596 & Small proline-rich protein $2 \mathrm{E}$ & 29 \\
\hline Dppa2 & NM_028615 & Mm.27857 & Developmental pluripotency associated 2 & 29 \\
\hline BB612626 & BB612626 & Mm.463155 & Not indicated & 26 \\
\hline Gap43 & NM_008083 & Mm.1222 & Growth associated protein 43 & 25 \\
\hline Sprr1b & NM_009265 & Mm.140151 & Small proline-rich protein $1 \mathrm{~B}$ & 23 \\
\hline Tspan 10 & NM_145363 & Mm.209875 & Tetraspanin 10 & 21 \\
\hline Tex 15 & NM_031374 & Mm.280624 & Testis expressed gene 15 & 20 \\
\hline $\operatorname{Prl} 7 \mathrm{a} 2$ & NM_011168 & Mm.153999 & Prolactin family 7 , subfamily a, member 2 & 19 \\
\hline Gm9519 & XR_391191 & Mm.389803 & Not indicated & 19 \\
\hline Nlrc5 & NM_001033207 & Mm.334720 & NLR family, CARD domain containing 5 & 19 \\
\hline Gm26579 & XR_380816 & Mm.356554 & Not indicated & 19 \\
\hline Aqp9 & NM_001271843 & Mm.335570 & Aquaporin 9 & 18 \\
\hline Sp110 & NM_175397 & Mm.335802 & Sp110 nuclear body protein & 18 \\
\hline Gm29824 & XR_870586 & Mm.135986 & ncRNA & 17 \\
\hline Sdr16c6 & BC125450 & Mm.298546 & $\begin{array}{l}\text { Short chain dehydrogenase/reductase family } \\
16 \mathrm{C} \text {, member } 6\end{array}$ & 17 \\
\hline Prl7a1 & NM_008930 & Mm.196424 & Prolactin family 7 , subfamily a, member 1 & 17 \\
\hline Cfhr2 & NM_001025575 & Mm.439660 & Complement factor H-related 2 & 17 \\
\hline $\mathrm{Fa} 2 \mathrm{~h}$ & NM_178086 & Mm.41083 & Fatty acid 2-hydroxylase & 17 \\
\hline Zfp352 & NM_153102 & Mm.214642 & Zinc finger protein 352 & 16 \\
\hline Cyp7a1 & NM_007824 & Mm.57029 & $\begin{array}{l}\text { Cytochrome P450, family } 7 \text {, subfamily a, } \\
\text { polypeptide } 1\end{array}$ & 16 \\
\hline Tvp23a & NM_001013778 & Mm.325732 & Trans-golgi network vesicle protein 23A & 15 \\
\hline Mmel1 & NM_013783 & Mm.116944 & Membrane metallo-endopeptidase-like 1 & 15 \\
\hline Ivl & NM_008412 & Mm.207365 & Involucrin & 15 \\
\hline Sprr2h & NM_011474 & Mm.10693 & Small proline-rich protein $2 \mathrm{H}$ & 15 \\
\hline AV154423 & AV154423 & Mm.486971 & Not indicated & 15 \\
\hline Phf11d & NM_199015 & Mm.479285 & PHD finger protein $11 \mathrm{D}$ & 15 \\
\hline Col8a1 & NM_007739 & Mm.130388 & Collagen, type VIII, alpha 1 & 14 \\
\hline Evi2a & NM_001033711 & Mm.439665 & Ecotropic viral integration site $2 \mathrm{a}$ & 14 \\
\hline Samd15 & NM_001290288 & Mm.302304 & Sterile alpha motif domain containing 15 & 14 \\
\hline Gm13119 & NM_001034101 & Mm.389596 & Not indicated & 14 \\
\hline Trp63 & NM_011641 & Mm.20894 & Transformation related protein 63 & 14 \\
\hline AA623943 & XM_006534607 & not indicated & Expressed sequence AA623943 & 14 \\
\hline Defb3 & NM_013756 & Mm.103651 & Defensin beta 3 & 14 \\
\hline Gm30692 & XR_863174 & not indicated & ncRNA & 14 \\
\hline Gm32204 & XM_006497575 & not indicated & Not indicated & 14 \\
\hline Serpinb2 & NM_011111 & Mm.271870 & $\begin{array}{l}\text { Serine (or cysteine) peptidase inhibitor, } \\
\text { clade B, member } 2\end{array}$ & 14 \\
\hline Rsad2 & NM_021384 & Mm.24045 & $\begin{array}{l}\text { Radical S-adenosyl methionine domain } \\
\text { containing } 2\end{array}$ & 14 \\
\hline Gm31115 & XR_390648 & not indicated & Not indicated & 14 \\
\hline Slco4a1 & NM_148933 & Mm.133687 & $\begin{array}{l}\text { Solute carrier organic anion transporter } \\
\text { family, member } 4 \mathrm{a} 1\end{array}$ & 14 \\
\hline Sod3 & NM_011435 & Mm.2407 & Superoxide dismutase 3 , extracellular & 13 \\
\hline Ccdc153 & NM_001081369 & Mm.347681 & Coiled-coil domain containing 153 & 13 \\
\hline
\end{tabular}


Table II. Continued

\begin{tabular}{|c|c|c|c|c|}
\hline Gene symbol & Accession & UniGene & Function & $\begin{array}{l}\text { Relative intensity } \\
\text { of } \mathrm{KO} / \mathrm{mock}\end{array}$ \\
\hline Lce1d & NM_027137 & Mm.176243 & Late cornified envelope 1D & 13 \\
\hline Twist2 & NM_007855 & Mm.9474 & Twist basic helix-loop-helix transcription factor 2 & 13 \\
\hline Plcb1 & NM_019677 & Mm.330607 & Phospholipase C, beta 1 & 13 \\
\hline Olfr376 & NM_001172686 & Mm.236410 & Olfactory receptor 376 & 13 \\
\hline Gm19619 & NR_040428 & Mm.125059 & Not indicated & 13 \\
\hline Dnm3 & NM_172646 & Mm.441620 & Dynamin 3 & 13 \\
\hline Chst5 & NM_019950 & Mm.432506 & $\begin{array}{l}\text { Carbohydrate (N-acetylglucosamine 6-O) } \\
\text { sulfotransferase } 5\end{array}$ & 13 \\
\hline BF119155 & BF119155 & Mm.432156 & Not indicated & 12 \\
\hline $\operatorname{Arg} 1$ & NM_007482 & Mm.154144 & Arginase, liver & 12 \\
\hline Cdh7 & AK034096 & Mm.487119 & Cadherin 7 , type 2 & 12 \\
\hline Ugt1a6b & NM_201410 & Mm.300095 & $\begin{array}{l}\text { UDP glucuronosyltransferase } 1 \text { family, } \\
\text { polypeptide A6B }\end{array}$ & 12 \\
\hline Chrna5 & NM_176844 & Mm.103778 & Cholinergic receptor, nicotinic, alpha polypeptide 5 & 12 \\
\hline Phf11a & NM_172603 & Mm.254918 & PHD finger protein $11 \mathrm{~A}$ & 12 \\
\hline Sh3tc2 & NM_172628 & Mm.262320 & SH3 domain and tetratricopeptide repeats 2 & 12 \\
\hline Armc2 & NM_001034858 & Mm.211320 & Armadillo repeat containing 2 & 12 \\
\hline Fgf21 & NM_020013 & Mm.143736 & Fibroblast growth factor 21 & 12 \\
\hline Ccdc109b & NM_025779 & Mm.31056 & Coiled-coil domain containing 109B & 12 \\
\hline Klk7 & NM_011872 & Mm.251227 & $\begin{array}{l}\text { Kallikrein related-peptidase } 7 \text { (chymotryptic, } \\
\text { stratum corneum) }\end{array}$ & 12 \\
\hline Sh3gl3 & NM_017400 & Mm.432002 & SH3-domain GRB2-like 3 & 11 \\
\hline Gm17202 & XR_389494 & not indicated & Not indicated & 11 \\
\hline Iigp1 & NM_021792 & Mm.261140 & Interferon inducible GTPase 1 & 11 \\
\hline AF067061 & NM_199060 & Mm.247428 & cDNA sequence AF067061 & 11 \\
\hline Plce1 & NM_019588 & Mm.34031 & Phospholipase C, epsilon 1 & 11 \\
\hline Tprg & NM_175165 & Mm.126851 & Transformation related protein 63 regulated & 11 \\
\hline Spint3 & NM_001177401 & Mm.234248 & Serine peptidase inhibitor, Kunitz type, 3 & 11 \\
\hline LOC 102634459 & XR_387206 & not indicated & Not indicated & 11 \\
\hline Gm4340 & NM_001177535 & Mm.339215 & Not indicated & 11 \\
\hline Arhgap9 & NM_001285785 & Mm.227198 & Rho GTPase activating protein 9 & 11 \\
\hline Aldh1a3 & NM_053080 & Mm.140988 & Aldehyde dehydrogenase family 1 , subfamily A3 & 11 \\
\hline Adh7 & NM_009626 & Mm.8473 & $\begin{array}{l}\text { Alcohol dehydrogenase } 7 \text { (class IV), mu or } \\
\text { sigma polypeptide }\end{array}$ & 11 \\
\hline $\operatorname{Pr} 13 \mathrm{~d} 2$ & NM_172155 & Mm.458451 & Prolactin family 3 , subfamily d, member 1 & 11 \\
\hline Lama1 & AK051116 & Mm.303386 & Laminin, alpha 1 & 11 \\
\hline Gm7978 & NM_001270457 & Mm.380154 & Not indicated & 11 \\
\hline BB114814 & XM_006508432 & Mm.304207 & Expressed sequence BB114814 & 11 \\
\hline D5Ertd577e & NM_177187 & Mm.348793 & DNA segment, Chr 5, ERATO Doi 577, expressed & 11 \\
\hline Lrrn4 & NM_177303 & Mm.386903 & Leucine rich repeat neuronal 4 & 11 \\
\hline Trav12-1 & ВC038136 & Mm.333502 & $\mathrm{T}$ cell receptor alpha variable $12-1$ & 11 \\
\hline CV783874 & CV783874 & Mm.441595 & Not indicated & 11 \\
\hline Igfbp5 & NM_010518 & Mm.405761 & Insulin-like growth factor binding protein 5 & 11 \\
\hline Gm3259 & NM_001270456 & Mm.402477 & Not indicated & 10 \\
\hline Gm4665 & AK132957 & Mm.437523 & Not indicated & 10 \\
\hline Sox11 & NM_009234 & Mm.41702 & SRY (sex determining region Y)-box 11 & 10 \\
\hline Tcstv1 & NM_018756 & Mm.302175 & 2-Cell-stage, variable group, member 1 & 10 \\
\hline Sprr3 & NM_011478 & Mm.57092 & Small proline-rich protein 3 & 10 \\
\hline Podn & NM_001285956 & Mm.74710 & Podocan & 10 \\
\hline Ifit $3 b$ & NM_001005858 & Mm.271850 & $\begin{array}{l}\text { Interferon-induced protein with tetratricopeptide } \\
\text { repeats } 3 \mathrm{~B}\end{array}$ & 10 \\
\hline
\end{tabular}


Table II. Continued

\begin{tabular}{|c|c|c|c|c|}
\hline Gene symbol & Accession & UniGene & Function & $\begin{array}{l}\text { Relative intensity } \\
\text { of } \mathrm{KO} / \mathrm{mock}\end{array}$ \\
\hline Gabra1 & NM_010250 & Mm.439668 & $\begin{array}{l}\text { Gamma-aminobutyric acid (GABA) } 1 \\
\text { A receptor, subunit alpha }\end{array}$ & 10 \\
\hline Ifi44 & NM_133871 & Mm.30756 & Interferon-induced protein 44 & 10 \\
\hline a & NM_015770 & Mm.315593 & Nonagouti & 10 \\
\hline $\mathrm{Rd} 31$ & XM_006515764 & Mm.134213 & Retinal degeneration 3-like & 10 \\
\hline Figf & NM_010216 & Mm.297978 & Vascular endothelial growth factor D & 10 \\
\hline B430212C06Rik & NR_033214 & Mm.491997 & Not indicated & 10 \\
\hline AK034098 & AK034098 & Mm.446266 & Not indicated & 10 \\
\hline Bank1 & NM_001033350 & Mm.30832 & B cell scaffold protein with ankyrin repeats 1 & 10 \\
\hline Sel113 & NM_172710 & Mm.235020 & Sel-1 suppressor of lin-12-like 3 & 10 \\
\hline Sgsm1 & NM_172718 & Mm.200203 & Small $\mathrm{G}$ protein signaling modulator 1 & 10 \\
\hline Krt13 & NM_010662 & Mm.4646 & Keratin 13 & 10 \\
\hline Тро & NM_009417 & Mm.4991 & Thyroid peroxidase & 10 \\
\hline Tnfrsf 18 & NM_009400 & Mm.491989 & $\begin{array}{l}\text { Tumor necrosis factor receptor superfamily, } \\
\text { member } 18\end{array}$ & 10 \\
\hline Klra2 & NM_008462 & $\mathrm{Mm} .4783$ & $\begin{array}{l}\text { Killer cell lectin-like receptor, subfamily A, } \\
\text { member } 2\end{array}$ & 10 \\
\hline Pcdh7 & NM_018764 & Mm.332387 & Protocadherin 7 & 10 \\
\hline Cbr2 & NM_007621 & Mm.21454 & Carbonyl reductase 2 & 10 \\
\hline Wnt3 & NM_009521 & Mm.159091 & $\begin{array}{l}\text { Wingless-type MMTV integration site } \\
\text { family, member } 3\end{array}$ & 10 \\
\hline AK042637 & AK042637 & not indicated & Not indicated & 10 \\
\hline CO811058 & CO811058 & Mm.421039 & Not indicated & 10 \\
\hline St18 & NM_173868 & Mm.234612 & Suppression of tumorigenicity 18 & 10 \\
\hline
\end{tabular}

Table III. Genes that are downregulated 10-fold or more in phosphatase and tensin homolog knockout cells.

\begin{tabular}{|c|c|c|c|c|}
\hline Gene symbol & Accession & UniGene & Function & $\begin{array}{c}\text { Relative intensity } \\
\text { of mock/KO }\end{array}$ \\
\hline Wtip & NM_207212 & Mm.422738 & WT1-interacting protein & 139 \\
\hline Gm32139 & XR_001782443 & not indicated & not indicated & 38 \\
\hline Gm38426 & NR_103491 & Mm.437155 & not indicated & 37 \\
\hline Ptgr1 & NM_025968 & Mm.34497 & prostaglandin reductase & 30 \\
\hline Pla2g16 & NM_139269 & Mm.274810 & phospholipase A2, group XVI & 29 \\
\hline Galnt14 & NM_027864 & Mm.271953 & $\begin{array}{l}\text { UDP-N-acetyl-alpha-D-galactosamine:polypeptide } \\
\mathrm{N} \text {-acetylgalactosaminyltransferase } 14\end{array}$ & 19 \\
\hline Dhrs4 & NM_030686 & Mm.27427 & dehydrogenase/reductase (SDR family) member 4 & 19 \\
\hline Fam124a & NM_001243857 & Mm.291864 & family with sequence similarity 124 , member A & 18 \\
\hline Robo1 & NM_019413 & Mm.310772 & roundabout guidance receptor 1 & 16 \\
\hline Evc2 & NM_145920 & Mm.25506 & Ellis van Creveld syndrome 2 & 15 \\
\hline Spats21 & NM_144882 & Mm.159989 & spermatogenesis associated, serine-rich 2-like & 14 \\
\hline Ttc12 & NM_172770 & Mm.177413 & tetratricopeptide repeat domain 12 & 14 \\
\hline Gxylt2 & NM_198612 & Mm.272037 & glucoside xylosyltransferase 2 & 14 \\
\hline Tmem173 & NM_028261 & Mm.45995 & transmembrane protein 173 & 13 \\
\hline Gm2030 & NM_001100445 & Mm.411645 & not indicated & 13 \\
\hline Gm16404 & NM_001220497 & Mm.380174 & not indicated & 13 \\
\hline Gm1993 & NM_001102677 & Mm.484626 & not indicated & 12 \\
\hline Gm10487 & NM_001100609 & Mm.483167 & not indicated & 12 \\
\hline Gm5168 & NM_001025607 & Mm.370361 & not indicated & 12 \\
\hline Slx & NM_001136476 & Mm.489202 & Sycp3 like X-linked & 12 \\
\hline $\mathrm{Scml} 2$ & NM_001290651 & Mm.159173 & sex comb on midleg-like 2 & 11 \\
\hline Gm14625 & NM_001220498 & Mm.477978 & not indicated & 11 \\
\hline Ppic & NM_008908 & Mm.4587 & peptidylprolyl isomerase $\mathrm{C}$ & 10 \\
\hline
\end{tabular}


A
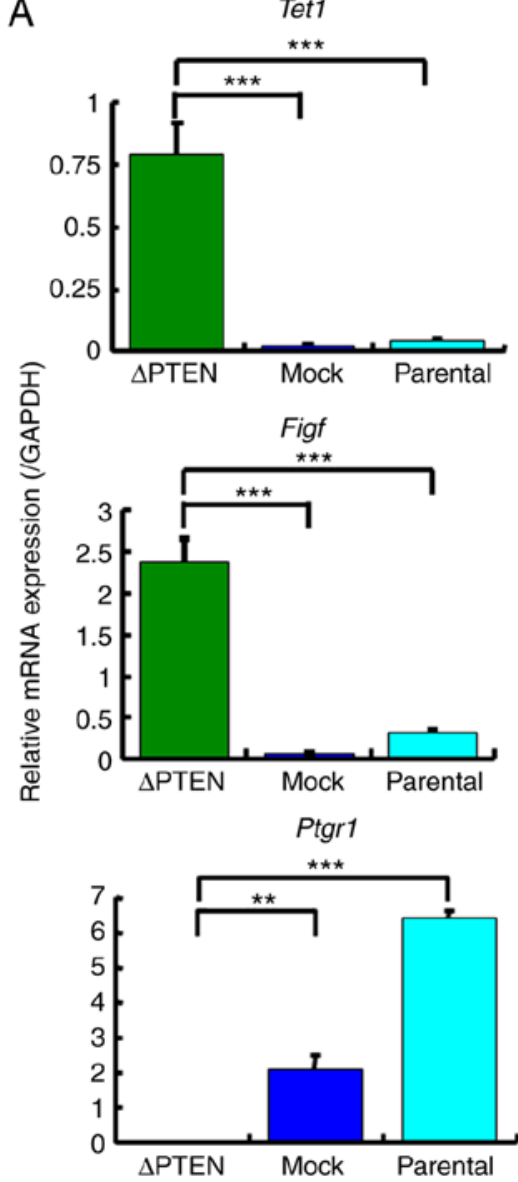
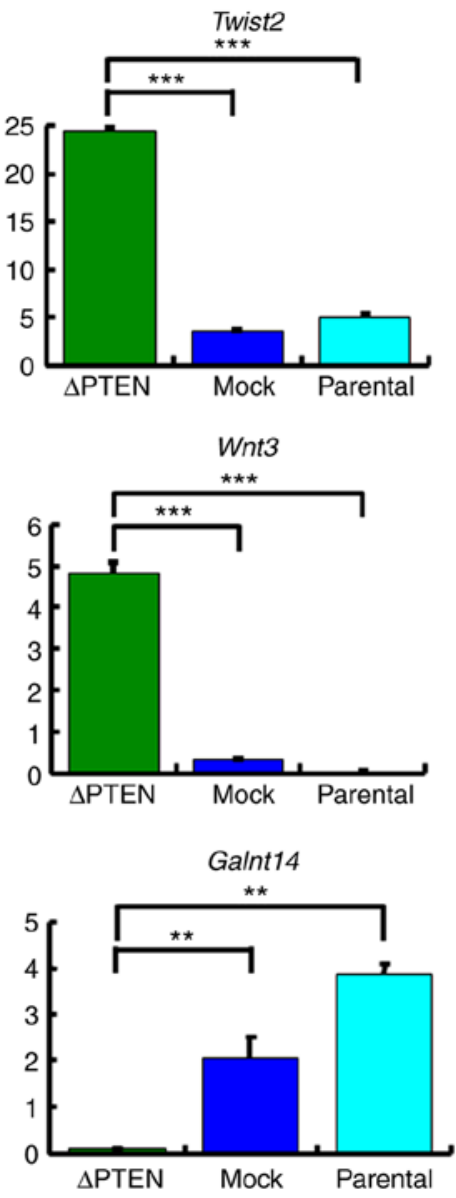
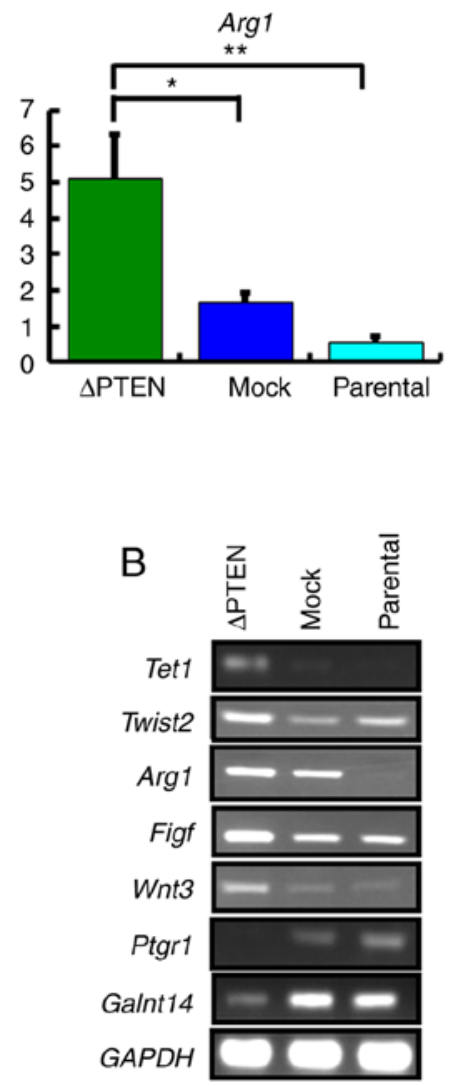

Figure 6. Confirmation of mRNA expression levels in selected genes with a $\geq 10$-fold change in the microarray analysis. (A) Expression levels of Tet1, Twist2, Arg1, Figf, Wnt3, Ptgrl, and Galnt14 in $\triangle$ PTEN, mock, and parental cell lines were analyzed using the qRT-PCR method. The relative gene expression levels are shown after normalization to GAPDH mRNA expression. (B) RT-PCR analysis of the mRNA expression of Tet1, Twist2, Arg1, Figf, Wnt3, Ptgr1 and Galnt14 in $\triangle \mathrm{PTEN}$, mock, and parental cell lines. ${ }^{*} \mathrm{P}<0.05 ;{ }^{* *} \mathrm{P}<0.01 ;{ }^{* * *} \mathrm{P}<0.001$. PTEN, phosphatase and tensin homolog; $\triangle \mathrm{PTEN}$, PTEN-knockout cell line; Tet1, Tet methylcytosine dioxygenase 1; Figf, C-fos-induced growth factor; Twist2 twist family BHLH transcription factor 2; Arg1, Arginase 1; Ptgr1, prostaglandin reductase 1; Galnt14, polypeptide N-acetylgalactosaminyltransferase 14; qRT-PCR, quantitative reverse transcription- polymerase chain reaction.

upregulated by at least 10 -fold, including one with a 74 -fold increase in $\triangle$ PTEN cells (Table II). In addition, 23 genes were identified to be substantially downregulated by $\geq 10$-fold, one with a 139-fold decrease (Table III).

The mRNA expression levels of Tet1, Twist2, Argl, Figf, Wnt3, Ptgrl, and Galnt 14 were measured by RT-qPCR to confirm the results of the microarray analysis (Fig. 6A). The expression patterns of the RT-PCR analysis were parallel to those in the microarray, thereby verifying the results (Fig. 6B).

Next, the present study performed gene enrichment profiling to gain better insight into the genes differentially expressed after PTEN-knockout in the model. The analysis using the Panther annotation database revealed that 64 of the 111 upregulated genes corresponded to 15 pathways (Fig. 7).

Furthermore, the expression of non-coding RNAs, in particular miRNAs, were assessed to further delve into the impact of PTEN inactivation and altered gene expression. Notably, the miRNA expression analysis in this study revealed that only the mmu-miR-210-3p expression increased ( $\geq 10$-fold) due to PTEN-knockout. Corroborating our initial observation, the RT-qPCR analysis presented an evident increase of mmu-miR-210-3p in $\triangle$ PTEN cells compared with the parental strain and mock-transfected cells (Fig. 8).

\section{Discussion}

The present study investigated the changes in carcinogenesis-associated genes caused by PTEN deficiency in a mouse prostate cancer model. A PTEN-deficient mouse prostate cancer isogenic cell line was established using the CRISPR/Cas9 system. The phosphorylation of Akt and the expression of cyclin D1 were elevated in PTEN-deficient cells. Although the expression of CDK7 wa srevealed to be decreased, the reason remains unknown. The expression levels of cyclinD1 and CDK4 that increased as demonstrated by western blotting, were not recognized as much different from that of parental cell or mock cell in microarray analysis. The reason for this increase in the expression currently remains unclear. Furthermore, microarray and miRNA arrays were used to assess the changes in gene expression. These results suggested that the PTEN expression is essential for normal gene expression.

The present study observed alterations in the expression levels of various genes due to the loss of the PTEN gene, which may be attributed to an increase in the expression of TET1. Demethylation is increased in several genes due to the enhanced expression of TET1, a dioxygenase that catalyzes the conversion of the modified genomic base 5-methylcytosine $(5 \mathrm{mc})$ 


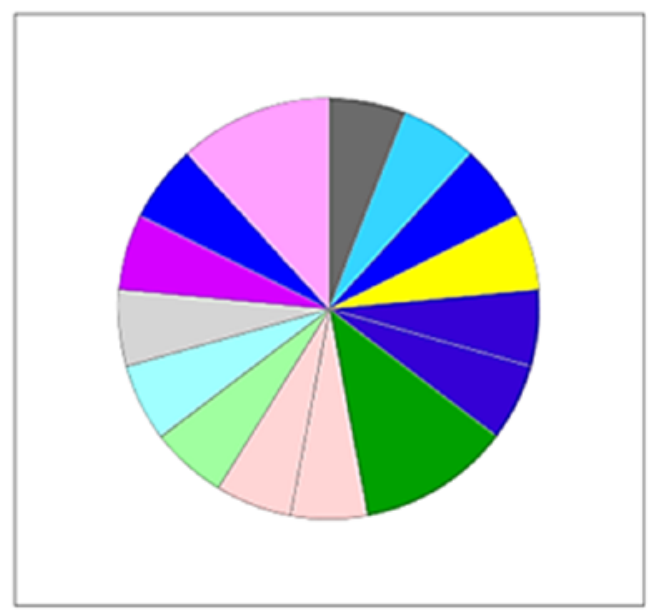

5-Hydroxytryptamine degredation (P04372)

5-HT2 type receptor mediated signaling pathway (P04374)

Alpha adrenergic receptor signaling pathway (P00002)

Alzheimer disease-presenilin pathway (P00004)

Blood coagulation (P00011)

CCKR signaling map (P06959)

Cadhering signaling pathway (P00012)

Histamine $\mathrm{H} 1$ receptor mediated signaling pathway (P04385)

Huntington disease (P00029)

Inflammation mediated by chemokine and cytokine signaling pathway (P00031)

$\underline{\text { Integrin signalling pathway (P00034) }}$

Oxytocin receptor mediated signaling pathway (P04391)

Plasminogen activating cascade (P00050)

Thyrotropin-releasing hormone receptor signaling pathway (P04394)

Wnt signaling pathway (P00057)

Figure 7. Biological processes and pathways altered in $\triangle$ PTEN cells. Panther gene ontology enrichment pie chart of genes upregulated after PTEN knockout. PTEN, phosphatase and tensin homolog; $\triangle$ PTEN, PTEN-knockout cell line.

into 5-hydroxymethylcytosine (5hmc). Reportedly, Nanog is an example of a gene induced by Tetl expression. Not only does Nanog have a role in the maintenance of mouse ES cells (20), but also in the maintenance of cancer stem cells, suppression of apoptosis, promotion of cancer progression and metastasis, and angiogenesis (21). These findings suggest that PTEN deficiency drives TET1 and TET1-gene regulation during carcinogenesis; however, the underlying reasons for an increase in the TET1 expression in PTEN deficiency remain unclear.

In this model, we established the upregulation of Twist2, Figf, Wnt3, and Argl in response to Pten-knockout; these genes play vital roles in the development and progression of cancer and promote the immune suppression in the surrounding tumor microenvironment.

Twist2, a member of the basic helix-loop-helix (BHLH) transcription factors, is overexpressed in several cancer types.

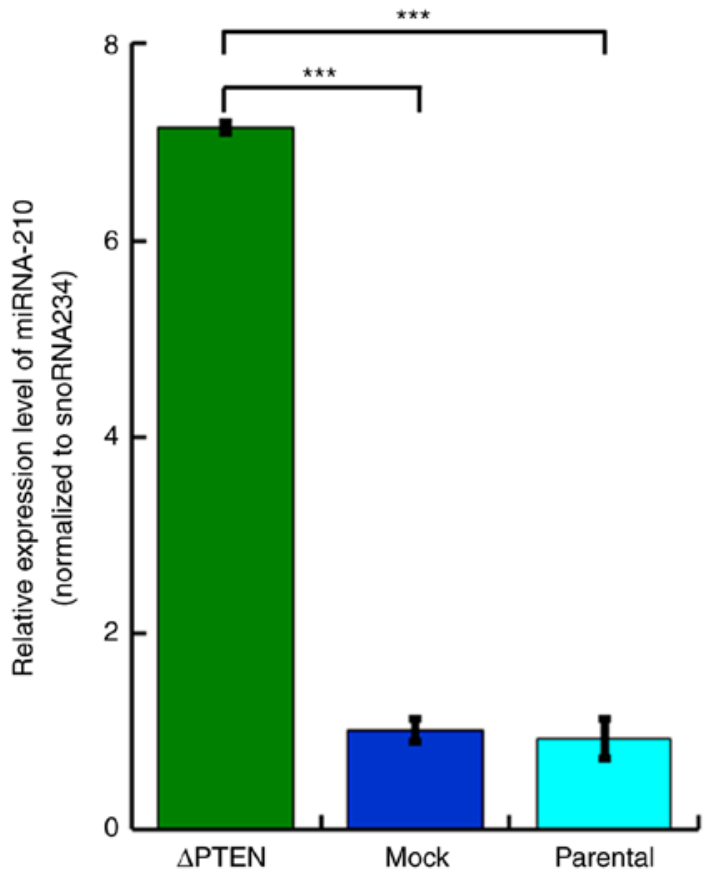

Figure 8. Analysis of miR-210 expression levels in $\triangle \mathrm{PTEN}$, mock and parental cell lines using reverse transcription-quantitative polymerase chain reaction. Results are normalized to snoRNA234 expression. ${ }^{* * *} \mathrm{P}<0.001$. PTEN, phosphatase and tensin homolog; $\triangle$ PTEN, PTEN-knockout cell line.

Previously, studies have reported the correlation of Twist expression with head and neck squamous cell carcinomas, cervical carcinomas, and ovarian cancer (22-24). Yang et al reported that hypoxia inducible factor-1 (HIF-1) promotes EMT through direct regulation of Twist expression (25). Twist is a master regulator of gastrulation and mesoderm specification and is implicated to be essential in the mediation of cancer metastasis (25). In this study, the expression of Twist was enhanced by the absence of functional PTEN, suggesting transcriptional regulation by mechanisms mediated by proteins other than HIF-1.

Figf, also termed vascular endothelial growth factor (VEGF)-D is a member of the platelet-derived growth factor (PDGF)/VEGF family and is active in angiogenesis and endothelial cell growth. Reportedly, the normal VEGF-D expression is detected in the lung, heart, skeletal muscle, skin, adrenal gland, and gastrointestinal tract (26-28). In addition, VEGF-D is upregulated in glioblastoma (29), melanoma (30), colorectal carcinoma (31), breast carcinoma (32), and cervical intraepithelial neoplasia (33). Tian et al reported that PTEN suppresses VEGF expression in HCC through both phosphatase-dependent and -independent mechanisms (34). The present study also implicated that PTEN regulates VEGF expression through both phosphatase- and HIF-1a- -independent mechanisms. Kaushal et al (35) reported that VEGF-D expression is observed in all prostate cancer tissues and that it is increased in samples at advanced stages compared with those at the early stage; however, they did not report the correlation between VEGF-D expression and PTEN. In $20 \%$ of prostate cancers, PTEN is deleted (36). PTEN-deficient prostate cancers express VEGF-D at an early stage; therefore, it is imperative to compare the expression between tumors with and without PTEN.

The Wingless-type MMTV integration site family genes comprise structurally related genes that encode a secreted 
signaling protein implicated in oncogenesis and several developmental processes, including the regulation of cell fate and patterning during embryogenesis $(37,38)$. In normal tissues, Wnt 3 RNA is primarily detected in the testis, skin, and brain. Reportedly, Wnt 3 is associated with cancer progression, invasion, and malignant conversion in cancer of the gastric (39), lungs $(40,41)$, and hepatocellular carcinoma $(42,43)$. In $\triangle$ PTEN cells, the cyclin D1 expression was upregulated. In addition, PTEN loss has been reported to augment cyclin D1 expression, although the underlying mechanism remains only partially understood. However, Zang et al reported that the Wnt/b-catenin pathway stimulates increased cyclin D1 levels in lymph node metastasis in papillary thyroid cancer (44). These results suggest an association between the PTEN-loss-induced Wnt 3 expression and the subsequent upregulation of cyclin D1.

In mammals, two arginase isoforms (Arg1 and Arg2) have been identified. Arg1 is known as the liver type and is expressed in hepatocytes (45). In mice, Arg1 can also be expressed in myeloid cells under the stimulation of T helper 2 cytokines interleukin (IL)-4 and IL-13 (46), transforming growth factor-b (47), macrophage-stimulating protein (48), or GM-CSF (49). Although immune responses are controlled by amino acid metabolism, Rodriguez et al reported that arginase produced by tumor-infiltrating macrophages repressed the expression of the T-cell receptor $\mathrm{CD} 3 \mathrm{z}$, resulting in the suppression of antigen-specific T-cell responses (46). In this study, it was observed that Arg1 expression increased following Pten deficiency; however, to the best of the author's knowledge, there are no reports demonstrating that Arg1 is highly expressed in any cancer other than liver cancer. Recent cancer treatment strategies have targeted arginine metabolism (50,51), thereby making Arg1 an attractive therapeutic approach for PTEN-deficient tumors.

The present study also analyzed differential expression of miRNA and observed an increased expression of mmu-miR-210-3p in the PTEN-deficient cell line. Reportedly, the expression of miR-210 is induced by HIF-1, which is known to be upregulated in PTEN-deficient cells (52). The expression levels of the target genes of miR-210 were not observed to be altered in the present study. Studies have suggested that miR-210 is involved in multiple processes, including angiogenesis, metastasis, oncogenesis, decreased cell division, and tumor suppression $(53,54)$. However, the exact function remains unclear and requires further investigation.

In conclusion, the present study established a mouse prostate cancer cell model of PTEN deficiency and provided evidence of altered expression of genes associated with the deregulation of signaling processes implicated in human cancers. Gene expression profiling suggested enhanced regulation cancer hallmarks, including cell proliferation, angiogenesis, metastasis, and immunosuppression. However, further studies are warranted to dissect and elucidate molecular mechanisms involved in promoting PTEN-deficient cancer progression.

\section{Acknowledgements}

Not applicable.

\section{Funding}

No funding was received.

\section{Availability of data and materials}

The datasets used during the present study are available from the corresponding author upon reasonable request.

\section{Authors' contributions}

AT, KY, SK, AO, HU, MADV, YK, SS, RU, TN and YH equally took part in the conception and design of the study, acquisition and interpretation of data, drafting the article and final approval of the version to be published.

\section{Ethics approval and consent to participate}

Not applicable.

\section{Patient consent for publication}

Not applicable.

\section{Competing interests}

The authors state that they have no competing interests.

\section{References}

1. Toker A and Cantley LC: Signalling through the lipid products of phosphoinositide-3-OH kinase. Nature 12: 673-676, 1997.

2. Li J, Yen C, Liaw D, Podsypanina K, Bose S, Wang SI, Puc J, Miliaresis C, Rodgers L, McCombie R, et al: PTEN, a putative protein tyrosine phosphatase gene mutated in human brain, breast, and prostate cancer. Science 28: 1943-1947, 1997.

3. Steck PA, Pershouse MA, Jasser SA, Yung WK, Lin H, Ligon AH, Langford LA, Baumgard ML, Hattier T, Davis T, et al: Identification of a candidate tumour suppressor gene, $M M A C 1$, at chromosome 10q23.3 that is mutated in multiple advanced cancers. Nat.Genet 15: 356-362, 1997.

4. Tamura M, Gu J, Matsumoto K, Aota S,Parsons R, and Yamada KM: Inhibition of cell migration, spreading, and focal adhesions by tumor suppressor PTEN. Science 280: 1614-1617, 1998.

5. Yamada KM and Araki M: Tumor suppressor PTEN: Modulator of cell signaling, growth, migration, and apoptosis. J Cell Sci 114: 2375-2382, 2001

6. Waite KA and Eng C: Protean PTEN: Form and function. Am J Hum Genet 70: 829-844, 2002.

7. McCall P, Witton CJ, Grimsley S, Nielsen KV and Edwards J: Is PTEN loss associated with clinical outcome measures in human prostate cancer? Br J Cancer 99: 1296-1301, 2008.

8. Davies MA: Regulation, role, and targeting of Akt in cancer. J Clin Oncol 29: 4715-4717, 2011.

9. Carnero A and Paramio JM: The PTEN/PI3K/AKT pathway in vivo, cancer mouse models. Front Oncol 4: 252, 2014.

10. De Velasco MA, Tanaka M, Yamamoto Y, Hatanaka Y, Koike H, Nishio K, Yoshikawa K and Uemura H: Androgen deprivation induces phenotypic plasticity and promotes resistance to molecular targeted therapy in a PTEN-deficient mouse model of prostate cancer. Carcinogenesis 35: 2142-2153, 2014.

11. Yamamoto Y, De Velasco MA, Kura Y, Nozawa M, Hatanaka Y, Oki T, Ozeki T, Shimizu N, Minami T, Yoshimura K, et al: Evaluation of in vivo responses of sorafenib therapy in a preclinical mouse model of PTEN-deficient of prostate cancer. J Transl Med 8: 150, 2015.

12. Koike H, Nozawa M, De Velasco MA, Kura Y, Ando N, Fukushima E, Yamamoto Y, Hatanaka Y, Yoshikawa K, Nishio K and Uemura H: Conditional PTEN-deficient mice as a prostate cancer chemoprevention model. Asian Pac J Cancer Prev 16: 1827-1831, 2015.

13. De Velasco MA, Kura Y, Yoshikawa K, Nishio K, Davies BR and Uemura H: Efficacy of targeted AKT inhibition in genetically engineered mouse models of PTEN-deficient prostate cancer. Oncotarget 29: 15959-15976, 2016. 
14. Jia L, Ji S, Maillet JC and Zhang X: PTEN suppression promotes neurite development exclusively in differentiating PC12 cells via PI3-kinase and MAP kinase signaling. J Cell Biochem 111: 1390-1400, 2010.

15. Khan FA, Pandupuspitasari NS, Chun-Jie H, Ao Z, Jamal M, Zohaib A, Khan FA, Hakim MR and Shujun Z: CRISPR/Cas9 therapeutics: A cure for cancer and other genetic diseases. Oncotarget 7: 52541-52552, 2016.

16. Ran FA, Hsu PD, Wright J, Agarwala V, Scott DA and Zhang F: Genome engineering using the CRISPR-Cas9 system. Nat Protoc 8: 2281-2308, 2013.

17. Mizuno S, Hanamura I, Ota A, Karnan S, Narita T, Ri M, Mizutani M, Goto M, Gotou M, Tsunekawa N, et al: Overexpression of salivary-type amylase reduces the sensitivity to bortezomib in multiple myeloma cells. Int J Hematol 102: $569-578,2015$

18. Mi H, Huang X, Muruganujan A, Tang H, Mills C, Kang D and Thomas PD: PANTHER version 11: Expanded annotation data from Gene Ontology and Reactome pathways, and data analysis tool enhancements. Nucleic Acids Res 45: D183-D189, 2017.

19. Livak KJ and Schmittgen TD: Analysis of relative gene expression data using real-time quantitative PCR and the $2^{-\Delta C_{\mathrm{T}}}$ method. Methods 25: 402-408, 2001.

20. Ito S, D'Alessio AC, Taranova OV, Hong K, Sowers LC and Zhang Y: Role of Tet proteins in $5 \mathrm{mC}$ to $5 \mathrm{hmC}$ conversion, ES cell self renewal and inner cell mass specification. Nature 26: $1129-1133,2010$.

21. Gawlik-Rzemieniewska N and Bednarek I: The role of NANOG transcriptional factor in the development of malignant phenotype of cancer cells. Cancer Biol Ther 17: 1-10, 2016.

22. Gasparotto D, Polesel J, Marzotto A, Colladel R, Piccinin S Modena P, Grizzo A, Sulfaro S, Serraino D, Barzan L, et al: Overexpression of TWIST2 correlates with poor prognosis in head and neck squamous cell carcinomas. Oncotarget 2: $1165-1175,2011$.

23. Li Y, Wang W, Wang W, Yang R, Wang T, Su T, Weng D, Tao T, Li W, Ma D, et al: Correlation of TWIST2 up-regulation and epithelial-mesenchymal transition during tumorigenesis and progression of cervical carcinoma. Gynecol Oncol 124: 112-118, 2012.

24. Mao Y, Xu J, Song G and Yin H: Twist 2 promotes ovarian cancer cell survival through activation of Akt. Oncol Lett 6: 169-174, 2013.

25. Yang MH, Wu MZ, Chiou SH, Chen PM, Chang SY, Liu CJ, Teng SC and Wu KJ: Direct regulation of TWIST by HIF-1alpha promotes metastasis. Nat Cell Biol 10: 295-305, 2008

26. Yamada Y, Nezu J, Shimane M and Hirata Y: Molecular cloning of a novel vascular endothelial growth factor, VEGF-D. Genomics 42: 483-488, 1997.

27. Achen MG, Jeltsch M, Kukk E, Mäkinen T, Vitali A, Wilks AF, Alitalo K and Stacker SA: Vascular endothelial growth factor D (VEGF-D) is a ligand for the tyrosine kinases VEGF receptor 2 (Flk1) and VEGF receptor 3 (Flt4). Proc Natl Acad Sci USA 95: 548-553, 1998.

28. Trompezinski S, Berthier-Vergnes O, Denis A, Schmitt D and Viac J: Comparative expression of vascular endothelial growth factor family members, VEGF-B, $-\mathrm{C}$ and $-\mathrm{D}$, by normal human keratinocytes and fibroblasts. Exp Dermatol 13: 198-105, 2004.

29. Debinski W, Slagle-Webb B, Achen MG, Stacker SA, Tulchinsky E, Gillespie GY and Gibo DM: VEGF-D is an $\mathrm{X}$-linked/AP-1 regulated putative onco-angiogen in human glioblastoma multiforme. Mol Med 7: 598-608, 2001.

30. Achen MG, Williams RA, Minekus MP, Thornton GE, Stenvers K, Rogers PA, Lederman F, Roufail S and Stacker SA: Localization of vascular endothelial growth factor-D in malignant melanoma suggests a role in tumour angiogenesis. J Pathol 193: 147-154, 2001 .

31. White JD, Hewett PW, Kosuge D, McCulloch T, Enholm BC, Carmichael J and Murray JC: Vascular endothelial growth factor-D expression is an independent prognostic marker for survival in colorectal carcinoma. Cancer Res 62: 1669-1675, 2002.

32. Nakamura Y, Yasuoka H, Tsujimoto M, Yang Q, Imabun S, Nakahara M, Nakao K, Nakamura M, Mori I and Kakudo K: Prognostic significance of vascular endothelial growth factor D in breast carcinoma with longterm follow-up. Clin Cancer Res 9: 716-721, 2003

33. Van Trappen PO, Steele D, Lowe DG, Baithun S, Beasley N, Thiele W, Weich H, Krishnan J, Shepherd JH, Pepper MS, et al: Expression of vascular endothelial growth factor (VEGF)-C and VEGF-D, and their receptor VEGFR-3, during different stages of cervical carcinogenesis. J Pathol 201: 544-554, 2003.
34. Tian T, Nan KJ, Wang SH, Liang X, Lu CX, Guo H, Wang W and Ruan ZP: PTEN regulates angiogenesis and VEGF expression through phosphatase-dependent and -independent mechanisms in HepG2 cells. Carcinogenesis 31: 1211-1219, 2010.

35. Kaushal V, Mukunyadzi P, Dennis RA, Siegel ER, Johnson DE and Kohli M: Stage-specific characterization of the vascular endothelial growth factor axis in prostate cancer: Expression of lymphangiogenic markers is associated with advanced-stage disease. Clin Cancer Res 11: 584-593, 2005.

36. Netto GJ: Molecular updates in prostate cancer. Surg Pathol 8: 561-580, 2015.

37. Clevers $\mathrm{H}$ : Wnt/beta-catenin signaling in development and disease. Cell 127: 469-480, 2006

38. He S, Lu Y, Liu X, Huang X, Keller ET, Qian CN and Zhang J: Wnt3a: Functions and implications in cancer. Chin J Cancer 34: 554-562, 2015

39. Wang HS, Nie X, Wu RB, Yuan HW, Ma YH, Liu XL, Zhang JY, Deng XL, Na Q, Jin HY, et al: Downregulation of human Wnt3 in gastric cancer suppresses cell proliferation and induces apoptosis. Onco Targets Ther 27: 3849-3860, 2016.

40. Nakashima $N$, Liu D, Huang CL, Ueno $M$, Zhang $X$ and Yokomise $\mathrm{H}$ : Wnt 3 gene expression promotes tumor progression in non-small cell lung cancer. Lung Cancer 76: 228-234, 2012.

41. Xing Z, Wang HY, Su WY, Liu YF, Wang XX, Zhan P, Lv TF and Song Y: Wnt3 knockdown sensitizes human non-small cell type lung cancer (NSCLC) cells to cisplatin via regulating the cell proliferation and apoptosis. Eur Rev Med Pharmacol Sci 22: 1323-1332, 2018.

42. Kim M, Lee HC, Tsedensodnom O, Hartley R, Lim YS, Yu E, Merle P and Wands JR: Functional interaction between Wnt 3 and Frizzled-7 leads to activation of the Wnt/beta-catenin signaling pathway in hepatocellular carcinoma cells. J Hepatol 48: 780-791, 2008.

43. Nambotin SB, Tomimaru Y, Merle P, Wands JR and Kim M: Functional consequences of WNT3/Frizzled7-mediated signaling in non-transformed hepatic cells. Oncogenesis 22: e31, 2012.

44. Zhang J, Gill AJ, Issacs JD, Atmore B, Johns A, Delbridge LW, Lai R and McMullen TP: The Wnt/ $\beta$-catenin pathway drives increased cyclin D1 levels in lymph node metastasis in papillary thyroid cancer. Hum Pathol 43: 1044-1050, 2012.

45. Bronte V and Zanovello P: Regulation of immune responses by L-arginine metabolism. Nat Rev Immunol 5: 641-654, 2005.

46. Rodriguez PC, Quiceno DG, Zabaleta J, Ortiz B, Zea AH, Piazuelo MB, Delgado A, Correa P, Brayer J, Sotomayor EM, et al: Arginase I production in the tumor microenvironment by mature myeloid cells inhibits T-cell receptor expression and antigen-specific T-cell responses. Cancer Res 64: 5839-5849, 2004.

47. Boutard V, Havouis R, Fouqueray B, Philippe C, Moulinoux JP and Baud L: Transforming growth factor- $\beta$ stimulates arginase activity in macrophages. Implications for the regulation of macrophage cytotoxicity. J Immunol 155: 2077-2084, 1995.

48. Morrison AC and Correll PH: Activation of the stem cell derived tyrosine kinase/RON receptor tyrosine kinase by macrophage-stimulating protein results in the induction of arginase activity in murine peritoneal macrophages. J Immunol 168: 853-860, 2002

49. Jost MM, Ninci E, Meder B, Kempf C, Van Royen N, Hua J, Berger B, Hoefer I, Modolell M and Buschmann I: Divergent effects of GM-CSF and TGFbetal on bone marrow-derived macrophage arginase-1 activity, MCP-1 expression, and matrix metalloproteinase-12: A potential role during arteriogenesis. FASEB J 17: 2281-2283, 2003.

50. Qiu F, Huang J and Sui M: Targeting arginine metabolism pathway to treat arginine-dependent cancers. Cancer Lett 364: 1-7, 2015.

51. Fultang L, Vardon A, De Santo C and Mussai F: Molecular basis and current strategies of therapeutic arginine depletion for cancer. Int J Cancer 139: 501-509, 2016.

52. Huang X, Ding L, Bennewith KL, Tong RT, Welford SM, Ang KK, Story M, Le QT and Giaccia AJ: Hypoxia inducible mir-210 regulates normoxic gene expression involved in tumor initiation. Mol Cell 35: 856-867, 2009.

53. Dang K and Myers KA: The role of hypoxia-induced miR-210 in cancer progression. Int J Mol Sci 16: 6353-6372, 2015

54. Ying Q, Liang L, Guo W, Zha R, Tian Q, Huang S, Yao J, Ding J, Bao M, Ge C, et al: Hypoxia-inducible microRNA-210 augments the metastatic potential of tumor cells by targeting vacuole membrane protein 1 in hepatocellular carcinoma. Hepatology 54: 2064-2075, 2011

This work is licensed under a Creative Commons Attribution-NonCommercial-NoDerivatives 4.0 International (CC BY-NC-ND 4.0) License. 